\title{
NEW FIRM CREATION-AN IMPORTANT RESEARCH STREAM EMERGE OF THE UNIVERSITY ENTREPRENEURSHIP
}

\author{
Associated Professor Szabo Zsuzsanna Phd, Petru Maior University, Tg.-Mures, \\ zsszabo@rdslink.ro \\ Lecturer Daniela Ştefanescu phd, Petru Maior University, Tg.-Mures, \\ daniela.stefanescu@gmail.com
}

\begin{abstract}
New firm creation seems to be one of the instruments available for university entrepreneurship which the recent literature expose the most understanding. In order to measure the university entrepreneurship, it should be taken into account the number of new firms created. Nowadays, the necessity to transform the universities in entrepreneurial one became a phenomenon all around the world, especially in developed countries. It is well recognized the necessity to adapt universities to the demands of a global, knowledge-based economy. Thus, the universities could become stronger players in the global knowledge society and economy. The phenomenon importance is well reflected on the literature, based on the increasing number of articles related to it. We also focused the connection between the university entrepreneurship and its significant contribution in promoting smes. The principal research question of this paper is to determine the current situation in united states, europe and the special case of Romania.
\end{abstract}

\section{Introduction}

Based on a detailed scientific literature analysis it was possible to identify the directions for further research and policy makers. The main four directions, as research streams of the university entrepreneurship are: (i) entrepreneurial research university, (ii) productivity of technology transfer offices, (iii) new firms' creation, (iv) environmental context including network of innovation. It is well recognized the necessity to adapt universities to the demands of a global, knowledge-based economy. Thus, the universities could become stronger players in the global knowledge society and economy. The phenomenon importance is well reflected on the literature, based on the increasing number of articles related to it.

\section{New firm creation}

One important stream related to the university entrepreneurship is new firm creation. The main instruments at the university level, which could be applied in order to sustain new firm creation, appear to be the spin-offs and business incubators.

Measurements of university entrepreneurship revolve around the quantity of new firms created, their performance - as revenues, growth, survival or failure, and also their attributes, as timing and location, rate of establishment, types, founding team characteristics.

In order to take into consideration the main factors this contributes to this stream of university entrepreneurship, new firm creation, the scholars have found the following elements: found university policy, faculty, technology transfer offices, underlying technology, investors, founding teams, networks in which a firm is embedded and also external conditions to affect the creation of new firm. 
Figure no.1 provides a schematic overview of this research stream and key aspects of every element.

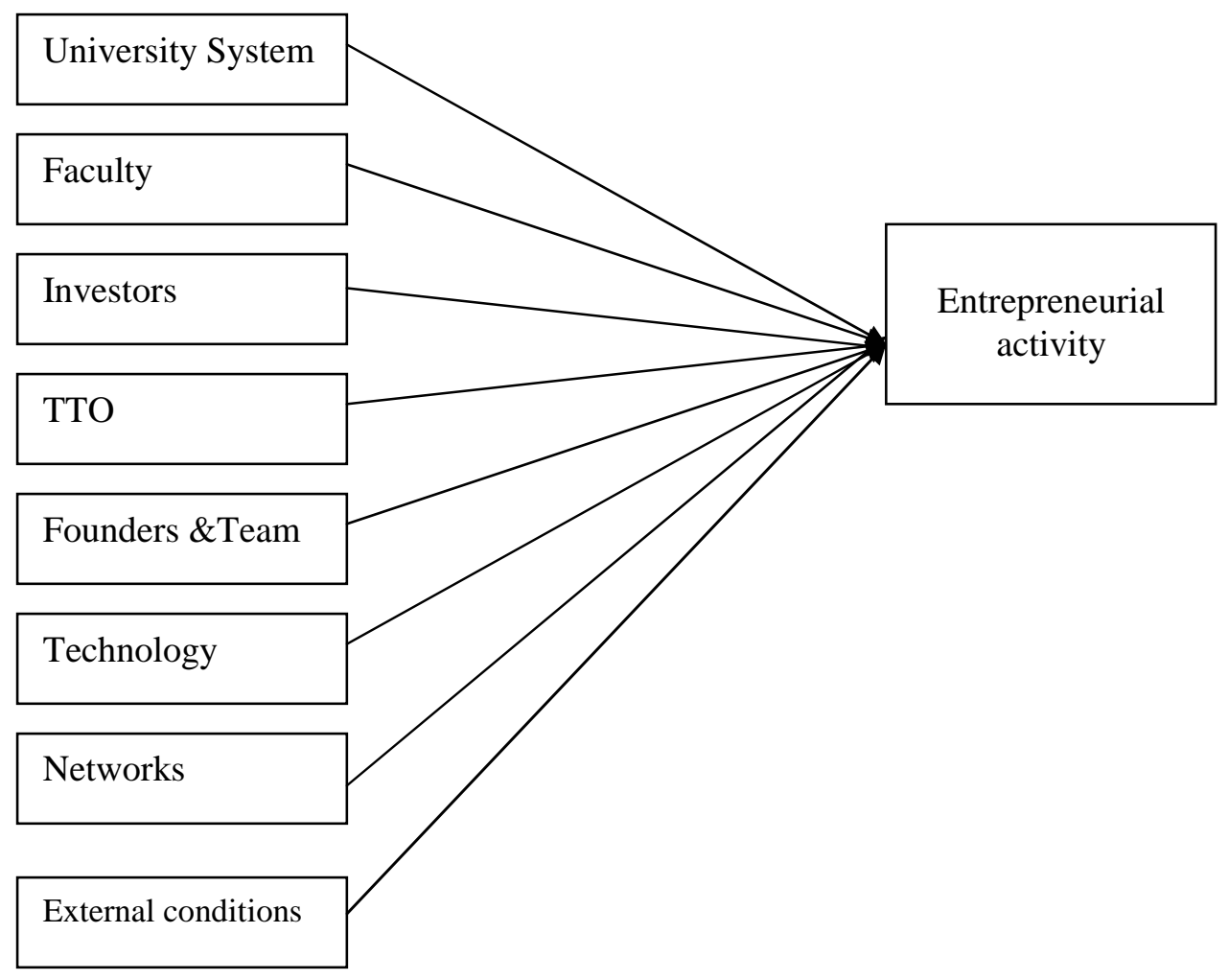

Figure no. 1 The new firm creation $[4,71]$

The university system is related to the different types of policies, as it is the attitude toward surrogate entrepreneurs preferred methods of transfer, intellectual property protection. In the same time, the university system includes the incubation models used: proactive, selective, supportive, planned or spontaneous, and also the research environment.

Aspects of the faculty include their location, roles in the new ventures, personality, expectations, quality, experience and timing of inventions.

The investors are important and they could contribute to the new firm creation depending on the informational gap, availability, relationship, and joint venture company arrangement.

The technological transfer offices (TTO) are significant through their presence, expectations, business capabilities, and experience.

Founders \& teams are showing their contribution to new firm creation based on their experience, the level of social capital, the evolution of the team, scientific excellence. A special importance is presented by the homogeneity of the team which involves in a new firm creation.

Regarding the technologies commercialized, the studies on the area revealed the effect of both the quantity and the quality of new venture creation. 
The presence of the networks is justified through the strength of ties, the formality of ties and of the collaboration.

The external conditions regard the industry R\&D funding, national or governmental resource fund, market opportunity and industry attractiveness.

The literature and the research in this field revealed various types of spin-outs. If it is take into account the transferee, spin-offs could be classified into three types: (a) technology only; (b) technology and personnel and (c) personnel only [1, 1-11]. Based on their business activities and resource requirements, spin-offs are classified into: (a) consultancy, (b) intellectual property licensing, (c) software, (d) product and (e) infrastructure creation [6,269-285]. Other characteristics of spin-offs concern the stage of its development. Development stages have been defined with reference to starts-up date, main business activities and critical resources needed.

Having in view to understand the nature of university spin-offs and to identify how manage the process of new firm creation, the literature reveals two approaches.

The first approach consists in identify the factors that impede the formation and growth of spin-offs, including informational gaps, unrealistic expectations, lack of competency in founding teams, resource scarcity and cultural problems. Cultural problems are comprised on an unsupportive university culture toward spin-offs, clash of culture between industry and academia, and a non-holistic approach, for example, focusing on technology and less on human or social aspects toward university spin-offs.

The second approach is the identification of success factors behind the process of new firm creation. On the literature, these types of factors revolve around four themes: intellectual property, networking activities of university spin-offs, resources and overall university involvement. University policies on intellectual property strategy, as the encouragement of equity investments are associated with a higher number of university spin-offs. In the same time, the university expenditure on external intellectual property protection is another factor that appears to contribute to the success of spin-offs.[10,63-71]

Another factor with an important impact on the success of the new venture is the networking activities of university spin-offs. The impact of this element depends on the frequency of interaction with external parties, such as firms, research institutes or public organizations. Another networking activities benefit identified on the literature is the ties with parent universities which provide infrastructure, expertise, and also the ties with venture capitalists have been shown to increase funding rates and decrease the probability of failure.

The resource endowments are presented in the literature as a success factor of university spin-offs. Prior research attributes success to the quality of human resources, including faculty, founding team, transfer technology offices personnel, technology endowment and funding from university, industry and venture capitalists.

A special issue in this literature stream is concerned with overall university system. Research on the impact of university systems comprises university policy, incubation models and research environments. The university involvement on newly created firms is presented different in the literature. Although the general accepted idea is that a high degree of involvement is beneficial for newly created firms, based on the higher survival rates, higher performance and greater reputation effects [5, 209-227], other sources demonstrate that greater university involvement could have as effect to dependency, non-beneficial reputation effects and delayed graduation from incubators [8,305-320].

Analyzing the founding teams of university-based technology ventures reveal that their composition affects the new firm performance. Team composition is related to founder affiliation, education profile and business experience. The result of literature study shows that the 
team heterogeneity is very important in order to conducive to superior firm performance. The founding team's heterogeneity endows the new venture with higher diversity of expertise, thus allowing the firm to better assess its opportunities and threats. Higher diversity increases team self-sufficiency, which has been found to negatively correlate with networking, an action that limits a firm's visibility and access to critical resources.

\section{Characteristics of new firm creation}

The experience gained in developed countries could be a real support for extended the phenomenon in East European countries, and also in Romania.

The literature in this stream represents a guide to learn from experience and to adjust the models which could be considering the best practice in the area. In this way, as model could be take into consideration the studies realized in United Kingdom. One of them realized on 14 university spin-offs and 14 company spin-offs being reveal how it is possible to assess new technology venture spin-offs from universities. The study shows the main assessment criteria categories: technological and commercial risks; level of product innovation; how to satisfies a market sector; market timeless; fitness into a family of products; longevity of product or process line; previous record of technological innovation, intellectual property rights.[3,535-543]. Another research which collected data from 48 UK universities shows that both the number of spin-out companies created and the number of equity investments in existing spin-outs are positively associated with university's expenditure on external intellectual property protection, business development capabilities of technology transfer offices and the royalty regime of the university. More successful universities have more explicit and proactive strategies towards development of spin-out companies. They also have more expertise and better networks. Their commercial offices have more important roles in opportunity recognition. The role of academic inventor is not significantly different. Equity appears to be distributed among interested parties. Successful universities always have an equity stake in spin-out companies.

Questioning how does the process involved in the spin-off policies affect the growth potential of the ventures? A study realized in Belgium on nine spin-offs policies in the eight largest academic institutions and in 47 firms' answers that the spin-offs policies involving strict selectivity combined with high support aid ventures capable in exploiting opportunities. On the other hand, the spin-offs policies with low selectivity and low support predispose venture to adopt small and medium size enterprise formats. In case of spin-offs policies involving strict selectivity combined with high support are more suited to environments with weak entrepreneurial structure and culture, but require a significant amount of resources. [4,327-352]

A research on 48 Italian spin-offs companies shows the profiles, opportunities and obstacles and reveals that they registered a modest growth rates. Very few cases of spin-offs companies were the result of planned initiatives by the mother institution. Barriers include stability and lifelong employment at universities, difficulty to obtain funding, entrepreneur's limited management skill. [2, 329-339]

The reason why some US universities generate more start-ups than others was shown on the researches result based on more than 100 US universities. The university policies making equity investments in lieu of patent and licensing costs, a low inventor share of royalties and the university intellectual eminence increase the creation of new firms. In the same time the studies reveal that the university has the most important organizational influence in the formation and development of the spin-offs in terms of the sources for ideas and personnel. It is also important as a source of consultants and research expertise. The federal government was identifying as the next important terms of a source of funding. Another aspect important related to the spin-offs 
success is the timing and the location of initial usage by both new dedicated biotechnology firms and new biotech subunits of existing firms are primarily explained by the presence at a particular time and place of scientists who are actively contribution to the basic science.

A special model is represented by the case of Swedish high-tech university spin-outs. The network relations consist of small number of strong ties that are characterized by high degree of trust and informality. Strong ties are fruitful for the transfer of complex knowledge and they cost less than building an intensive social network. Yet, strong ties make spin-offs dependent on continuous support of basic research.

In Canada, a research based on data collected from 38 start-up firms created by entrepreneurs at universities shows that there is a difference in the growth behavior and dynamics between technical service firms and manufacturing firms. There is a seemingly negative effect on the growth and development of manufacturing firms with continuing contracts with the university.

The Romanian papers that approach entrepreneurship and the entrepreneurial education are rare, and, in order to follow the stream on the international level, regarding the entrepreneurial education on universities, it is necessary to learn from others experience. In order to sustain the new firm creation in Romania, Aurel Vlaicu University Arad made the first step, establishing a business incubator, as a link between the university and economic environment, and also, in order to promote the staff teaching research subjects and invention. Another example is represented by the Technical University Timisoara, where in 2004 was establish a business incubator and a centre for technology transfer. Since February 2006 in the business incubator of Timisoara Technical University were created ten software companies.

\section{Conclusions}

The main streams of literature on university spin-off activities could be concluded as follows:

- $\quad$ individual and personality of the individual as the key determinant of whether spin-off activity occurs;

- $\quad$ organizational configuration studies explaining spin-off activity in terms of the resources of the university;

- $\quad$ social-cultural development studies explaining spin-offs activity in terms of culture and rewards within the university;

- $\quad$ studies explaining spin-offs in terms of external environmental influences;

- $\quad$ measurements of the performance of spin-offs;

- $\quad$ measurements of the economic impact of spin-off activity.

The literature on new firm creation treats also as a significant issue the founder's social network. Social networks have been identified as having implications on the type of spin-out, particularly to what extend technology and human resources are transferred into the newly created firms, as well as the spin-outs' performance. Prior research has not addressed what particular advantages a spin-out firm would gain from one type of spin-out versus alternative forms, such as technology only versus personnel only versus technology and personnel, given a founder's social network. Moreover, a founding team' social ties, either formal or informal, linking different resources to generate distinctive advantages may constitute another area for organizational and strategy research. 



\section{Bibliography:}

[1] Carayannis E. G., Rogers E.M., Kurihara K and Allbritton M.M., High-technology spin-offs from government $R \& D$ laboratories and research universities, Technovation, 18, 1998

[2] Chiesa V., Piccaluga A., Exploitation and diffusion of public research: the case of academic spin-off companies in Italy, R\&D Management, 30, 2000

[3] De Coster R., Butler C., Assessment of proposal for new technology ventures in UK: characteristics OF University spin-offs companies, Technovation, 25 (5), 2005

[4] Degroof J. J., Roberts E. B., Overcoming weak entrepreneurial infrastructures for academic spin-offs ventures, Journal of Technology Transfer, 29, 2004

[5] Di Gregorio D., Shane S., Why do some universities generate more start-ups than others?, Research Policy, 32, 2003

[6] Druilhe C., Garnsey E., Do academic spin-outs differ and does it matter?, Journal of Technology Transfer, 29, 2004

[7] Nicolaou N., Birley S., Academic networks in a trichotomous categorization of university spinouts, Journal of Business Venturing, 18, 2003

[8] Rothaermel F. T., Agung S.D., Jiang L., University Entrepreneurship: A Taxonomy of the Literature, Industrial and Corporate Change, Oxford University Press, July, 2007

[9] Rothaermel F. T., Thursby M. C., University - incubator firm knowledge flows: assessing their impact on incubator firm performance, Research Policy, 34, 2005

[10] Samson K. J., Gurdon M. A., University scientists as entrepreneurs: a special case of technology transfer and high-tech venturing, Technovation, 13, 1993 